International Journal of Accounting \& Information Management Volume 26, Issue 3, 2018, ISSN:1834-7649, Emerald publication.

\title{
Audit Committee Adoption and Firm Value: Evidence from UK Financial Institutions
}

Accepted for Publication in July 2017

\author{
${ }^{1}$ Peter Agyemang-Mintah $\quad{ }^{2}$ Hannu Schadewitz
}

$1,{ }^{2}$ Turku school of Economics, University of Turku-Finland

Department of Accounting and Finance, Rehtorinpellonkatu 3, 20500 Turku

Postal Address: 20014 Turun yliopisto Finland 


\begin{abstract}
Purpose: This study examines the impact of audit committee (AC) adoption on the financial value of financial institutions in the UK and also examines the impact of the establishment of an audit committee on firm value during the pre/post global financial crisis era.

Design/methodology/approach: The paper embarks on a theoretical and empirical literature review on audit committee (AC) adoption and its impact on the firm's financial value. The paper uses data from 63 financial institutions and covers a 12-year period.

Findings: The empirical results indicate that the adoption of an $\mathrm{AC}$ by financial institutions has a positive and statistically significant impact on firm value. The results from the precrisis period also indicate the adoption of an AC makes a positive and significant contribution to firm value. However, there is no impact on firm value during the post-crisis period. Our results suggest that the entire UK economy experienced an economic downturn after the financial crisis (2009-2011) and financial firms were no exception.

Research limitations/implications: Our study helps to fill research gaps on the relationships between ACs and firm value as they exist in UK financial institutions. These findings are important for policy-makers and regulators.

Originality/value: To the best of our knowledge, this research is the first to conduct an empirical study of the effect of AC adoption on UK financial institutions and firm value. Second, no single study has been conducted on the effects of AC adoption and its impact on either the pre- or the post-financial crisis periods. This is the first paper to provide such empirical evidence.
\end{abstract}

Keywords: Audit committee adoption, financial institutions, UK, pre- and post-financial crisis, firm's value.

Paper type: Empirical research.

\title{
1. Introduction
}

Shareholders appoint a board of directors to scrutinise the highest decisions made within a firm (Fama, 1980; Vafeas and Theodorou, 1998). The appointment is required by state or country incorporation laws. Boards also provide solutions to organisational problems, by monitoring and advising executives on important decisions concerning the firm (Bozec, 2005; Baldenius et al. 2014). The monitoring or advising of the board is intended to protect shareholder interests by providing an objective and independent review of the actions taken by corporate executives to reduce agency conflicts (Klein, 1998; Fama and Jensen, 1983). The directors on the board form part of the firm's internal governance mechanism, which ensures that the interests of shareholders and managers are closely aligned (Kang et al. 2007).

According to the Cadbury Report, 1992, the Combined Code, 2003, 2006, and the FRC, 2016, a board of directors should establish board committees for auditing, remuneration nomination, etc., to help improve efficiency. These committees are classified as key committees because of their contribution to organisational success as they help to assist in the dispatch of business activities by considering more detail than would be convenient for the whole board. Also, these committees enhance a firm's corporate governance policies and improve investor confidence, eventually improving financial performance (Charkham, 2005; FRC, 2014; 2016; Cadbury Report, 1992; Combined Code, 2003, 2006). All such committees scrutinise decisions and solve organisational problems. This research aims to narrow down 
and focus on the adoption or the establishment of an audit committee (AC) as being one of the most important functions of the board of directors.

Generally, there should be at least three AC members, or in the case of smaller companies, it can be two non-executive directors. The members should be independent and contain experience and ethical repute for making the right decisions and ensuring that the interests of shareholders are protected in relation to financial reporting and internal control. The requirements for the establishment of $\mathrm{AC}$ in the $\mathrm{UK}$ are consistent with that of India, another Commonwealth country (FRC, 2016; Khosa, 2017).

In the same vein, the functions of an $\mathrm{AC}$ are to monitor and review the integrity of their firm's financial statements and audit process and risk management systems. Further functions include the following: to ensure professional judgement and help meet audit standards and make recommendations to the board and shareholders regarding the appointment, reappointment and removal of an external auditor. Also, the functions of the AC are to approve the remuneration and terms of engagement of the external auditor and review audit fees and fees paid for any non-audit work. The AC implements policy on the engagement of the external auditor concerning the supply of non-audit services, serving as a bridge between the internal auditors, external auditors and the board of directors. The AC is involved in whistle blowing, reviewing and monitoring the external auditor's independence and objectivity, ensuring the timely release of unbiased accounting information by managers to shareholders as well as helping to avoid financial fraud and increase firm performance (Smith review, 2003; Klein, 1998; FRC, 2014 \& 2016; Mallin, 2006; Walker review, 2009; Chong, 2015).

Based on these AC functions, we empirically examine whether their adoption in UK financial institutions can have an impact on the financial value of firms.

The first motivation for conducting this research is that the $\mathrm{AC}$ is the only committee that requires at least one of its members to have recent and relevant financial experience and that their duties should follow relevant UK professional and regulatory requirements (FRC, 2014, 2016; Khosa, 2017). However, there is no strict regulatory requirement for the adoption of a nomination process or remuneration committee by the board. This makes the establishment of an AC crucial to the board's success and creates an avenue by which to ascertain empirically if its establishment has a significant impact on firm value.

The second motivation for embarking on this research is that there have been numerous corporate governance reforms in the UK (e.g., Cadbury Report, 1992; Greenbury, 1995; Hampel, 1998; Combined Code, 2003, 2006; Turnbull, 1999, 2005; Myners, 2001; FSA review, 2002; Higgs, 2003; Tyson, 2003; Smith review, 2003; Turner review, 2009; Walker review, 2009; Financial Services Bill, 2010 and the Financial Reporting Council, 2014 \& 2016) to help firms improve their corporate governance policies. However, the adoption of these codes by firms is on a voluntary basis; this means that firms are not obliged to comply with the provision once they have reasons for non-compliance. The Comply or Explain principles governing corporate governance adoption in the UK make it very interesting to conduct an empirical study as this creates a situation where it is optional for firms to comply with the adoption of the $\mathrm{AC}$ code, even though it is considered to be one of the most crucial committees for the success of a board of directors. Thus, an empirical study of firms that have adopted an $\mathrm{AC}$ is worthwhile undertaking.

The third motivation driving this research is the need to ascertain how these financial firms performed during the pre- and post-financial crisis periods when they had an AC in place. This should provide a clear picture of the importance of an AC during any period. To the best 
of our knowledge, this is the first study to address the impact of AC adoption on UK financial institutions.

The final motivation steering this research is that there is a paucity of empirical AC research into banks and other financial institutions and it is very rare to find it in accounting literature. This makes research of ACs that references UK financial firms worthwhile as it helps to fill a gap in accounting literature and make an important contribution to knowledge on audit committees.

This AC research will be centred on UK financial institutions as the UK is one of the worldleading hubs for the financial services industry. The sector offers products such as banking, insurance, mortgages, asset management and mutual funds to stakeholders (BoE and $\mathrm{HM}$ Treasury, 2015). Conducting research into financial institutions is unique and different from non-financial firms because the sector is highly regulated and deposits are paid to the Bank of England (BoE) as insurance for customers, thus avoiding any uncertainty (Macey and O'Hara, 2003; Zagorchev and Gao, 2015). In the same vein, research into financial institutions in the UK is also unique because the government regulation of these firms is supported by international bodies such as the International Corporate Governance Network (ICGN), Organisation for Economic Co-operation and Development (OECD) and International Regulatory Framework for Banks (Basel III), etc. These organisational bodies help to create global standards for these institutions. The adoption of an AC will ensure that they comply with regulations that can affect a firm's financial statement. Finally, financial institutions are more volatile than other sectors of the economy and require strict oversight responsibility, which is accomplished by the adoption of an AC (Macey and O'Hara, 2003; Zagorchev and Gao, 2015).

To conduct an empirical study into these motivations, this research explores the following questions: first, what were the financial impacts of the adoption of ACs by UK financial institutions? Second, what were the effects of the AC on firm value during the pre- and postfinancial crisis periods? The research findings reveal that the adoption of an AC has a positive and statistically significant relationship with a firm's value. A further investigation indicates a positive and statistically significant association between $\mathrm{AC}$ and firm value during the pre-crisis but a weak one during the post-crisis era. A reasonable explanation may be that, after the financial crisis (2009-2011), the entire UK economy was experiencing an economic downturn and financial firms were no exception, irrespective of whether they had an AC in place or not.

The remainder of the paper is organised as follows: Section 2 discusses the theoretical literature review, which covers the agency theory, the financial crisis and prior audit committee studies as well as the development of the hypotheses. Section 3 presents the research method, data and sample selection, the regression design and the test for multicollinearity. Section 4 describes the empirical discussions and findings of this research, tests for the robustness of the results and control for endogeneity. Section 5 provides the summary and conclusion of the study, outlines its limitations and suggests potential areas for future research. 


\section{Theoretical Literature Review}

\subsection{The principal-agent conflict and agency theory}

Agency theory is defined as "one in which one or more persons (the principal(s)) engage another person (the agent) to perform some service on their behalf which involves delegating some decision-making authority to the agent" (Jensen and Meckling, 1976).

The relationship between the principal and the agent possesses two major interdependent problems. The first is the problem of information asymmetry between the principal and the agent. The second is the possibility of conflicts or a divergence of interest between the principal and the agent (Hill and Jones, 1992). In terms of divergence of interest, the agent does not necessarily make decisions in the best interests of the principal. The agent (manager) may prefer to pursue their own personal objectives instead of the primary objective of wealth maximisation for shareholders (Huse, 2007; Eisenhardt, 1989; Berle and Means 1932).

The formation of an $\mathrm{AC}$ by the board of directors is designed to overcome agency problems and helps enhance the firm's monitoring and effectiveness. However, a recent study by Khosa (2017) indicates that the presence of an AC can mitigate the agency costs between managers and shareholders. Also, the establishment of an AC helps to align the interests of management with those of the shareholders (Hillman and Dalziel, 2003). The establishment of an $\mathrm{AC}$ as part of best corporate governance practice helps to reduce agency costs and information asymmetry by ensuring that a firm's activities are conducted in line with the expectations of the principal and the agent.

\subsection{The financial crisis - a brief background}

As the third motivation of this research is to ascertain how these financial firms performed during the pre- and post-financial crisis periods when there was an $\mathrm{AC}$ in place, this section provides a brief review of the global financial crisis and its impact on firms.

The financial crisis in 2007/2008 started due to the collapse of the real estate market in the US, which spread to other countries including the United Kingdom. The crisis occurred when the subprime mortgages that were the first symptom of a credit boom began to result in bankruptcies (Mizen, 2008). The banks and other financial institutions were also involved in producing innovative products such as mortgage securitisation, derivative trading, and short and long sales that were highly risky and contributed to the crisis.

In the UK, the crisis led to the collapse of financial institutions and exposed weaknesses in them. Banks such as Bradford \& Bingley, HBOS, Lloyds TSB, Northern Rock, the Royal Bank of Scotland and many others were affected. The UK government bailed out these institutions out of their financial difficulties because there were issues with their risk management approach which ultimately affected their firm value and reduced their cash flow (Krause and Tse, 2016). The government also increased borrowing and urged banks and other financial institutions to do the same. The interest rate was cut to $0.5 \%$ to make it easier to borrow.

The responsibility of the AC also covers risk management systems in the firm. This means that a financial firm's performance during the pre- and post-crisis periods is important to AC 
board members ${ }^{3}$ (HM Treasury Committee Report, 2009, FRC, 2016). The AC needs to plan their audit strategy in order to reduce audit risk level (Chong, 2015). The financial sector provides a major economic boost to the UK as it provides employment for people, tax revenue to the government and foreign exchange to the economy by offering services such as banking, insurance, mortgages, asset management, currency trade and mutual fund investment. The financial sector in UK is also the world's second biggest financial market after the USA (BoE and HM Treasury, 2015; Mintah 2016).

\subsection{Prior audit committee studies and hypotheses development}

Empirical research on ACs and financial institutions is very rare, and none has been found on this study's specific line of enquiry. This makes research on ACs and UK financial institutions a particularly worthwhile undertaking. Consequently, empirical studies in support of this paper are based on broad AC research and are not specific to financial institutions. For example, research by Wild (1994) indicates that firms see a significant increase in their financial performance when they put an AC in place. However, Menon and Williams (1994) suggest that the mere formation of an $\mathrm{AC}$ does not mean that a board of directors can solely depend on it to enhance the monitoring of their firm and help increase its financial performance. Research conducted by Conyon (1994) indicated that $90 \%$ of large, UK-quoted firms had an AC in place in 1993. Supporting Conyon's (1994) research is a study by Collier (1993) which analysed AC adoption for 142 UK firms and stated that their adoption of an AC was in line with their agency cost of equity, debt and information asymmetry.

Carcello et al. (2002) examined board characteristics and audit fees and found that board independence and audit fees are positively correlated. They argued that an independent AC demands higher audit quality than normal standards, even higher than external auditors charging higher fees. In similar studies, Carcello and Neal (2003) and Felo et al. (2003) documented a positive relation between $\mathrm{AC}$ independence and financial reporting quality.

Van der Zahn and Tower (2004) studied the relationship between AC and earnings management using a sample of 485 firms from Singapore between 2000 and 2001. Their findings indicate that $\mathrm{AC}$ members who have greater independence are more effective and diligent. Research by Choi et al. (2004) found that larger ACs are effective and include members with varied professional expertise to perform and monitor financial reporting practices. This outcome is in line with the Financial Reporting Council (2016) provision on the adoption of AC by firms. In a similar line of enquiry, Karamanou and Vafeas (2005) found that managers in firms with effective board and AC structures are likely to make a precise and accurate forecast which is more favourable to market responses. This empirical research shows that a good AC is linked to better financial disclosure quality. The reason for this is that the AC can scrutinise financial information thoroughly and ensure it is free from errors.

Furthermore, Defond et al. (2005) observed that the announcement of 850 newly appointed outside directors to ACs between 1993 and 2002 showed a significant, positive and exceptional return for the companies. Zha (2006) used a sample of firms from 2002 to 2004, immediately after the release of the Code of Conduct by the Chinese Securities Regulatory Commission (CSRC) and found that firms with an $\mathrm{AC}$ in place have the propensity to increase their financial performance.

\footnotetext{
3 The UK Government has an $82 \%$ stake in RBS as a result of bailing out the bank with taxpayers' money.
} 
According to Munisi and Randøy (2013), an AC is positively and significantly associated with company performance. This result is based on publicly listed companies across SubSaharan African countries. This means that firms with an AC can expect to achieve higher performance. Chan and Li's (2008) research reveals that the establishment of these committees (audit, nominating and compensation) have a positive impact on firm value since their knowledge and experience can be shared during board meetings. Also, the information given by a committee can enhance the overall insight of a board of directors into their firm.

According to Bruynseels and Cardinaels (2014), an AC provides oversight regarding the auditing process and ensures the quality of financial reporting to stakeholders. Their empirical results show that audit committee activities are positively associated with a firm's total accruals. Karim et al. (2013) carried out a research in Bangladesh using a sample of 129 IPOs companies over the 17-year period from 1990 to 2006; this work indicated that high audit quality can influence a firm's accounting information delivery and can have a significantly positive impact on it.

In contrast to the benefits gained by firms as a result of establishing an AC, prior studies indicate that the presence of an AC can have no impact or a negative impact on a firm. Empirical research by Khosa, (2017) indicates that AC independence is negatively associated with firm value, when he conducted a research using a sample of 317 listed firms from India, comprising 1,350 firm-year observations for the period 2008-2012. Bradbury et al.'s (2006) research on board of director and AC size on firms in Singapore and Malaysia shows a significantly negative correlation with Tobin's Q (firm value). This research is consistent with the findings of Yermack (1996), where a sample of 452 large US industrial corporations between 1984 and 1991 showed that the establishment of an AC board had a negative correlation to a firm's Tobin's Q.

Other research on ACs shows no significant relationship to firm performance. For example, a study by Rahman and Ali (2006) found no significant relationship between audit committee independence and earnings management among Malaysian public listed companies. The reason for this is that boards of directors are considered to be ineffective in discharging their monitoring duties due to management's dominance of board matters.

However, given the mixed empirical evidence, this research predicts that ACs in UK financial institutions can have either a positive or negative association with firm value, as a measure of financial performance. Henceforth, the main hypotheses to be tested are as follows:

H1: There is a positive and statistically significant relationship between the existence of an audit committee and a firm's value as a measure of financial performance in UK financial firms.

H2: There is either a positive or a negative relationship between the existence of an audit committee and a firm's value as a measure of financial performance in UK financial firms during the pre-and post-financial crisis periods. 


\section{Research Method}

\subsection{Data and sample}

This research paper uses secondary data from DataStream (Thomson Reuters) and covers a 12-year period of 63 financial firms' annual reports (from December 2000 to December 2011). The financial firms include representatives from the investment banking, insurance, mortgage, investment trust and banking services sectors.

The firms were selected to be part of the sample by using the criteria that they have had 12 consecutive years of annual reports, and that the independent variables (audit committee information), dependent variable (Tobin's Q) and control are available on DataStream (Cheng et al. 2008; Mintah, 2015; Krause and Tse, 2016).

The decision to use a financial institution's annual report is consistent with previous empirical studies (e.g., Botosan 1997; Ho and Williams, 2003; Cheung et al., 2006; Mangena and Chamisa, 2008; Ntim et al., 2013; Zagorchev and Gao, 2015; Mintah, 2015).

The 63 financial firms generate 756 firm-year observations, which are sufficient to help answer the research questions and make a meaningful contribution to AC literature. Also, selecting data from 2000 to 2011 is appropriate to the research objectives and the rationale behind this study.

The sample used is large when compared with previous empirical studies such as, for example, Zagorchev and Gao (2015), who obtained 41 corporate governance datasets from US to cover the period 2002-2009; Aanu et al. (2014), who used 25 firms in Nigeria from 2004 to 2011; Fire and Meth (1986), who obtained 36 annual reports in order to study the information requirements for the analysis of investment by companies; and April et al. (2003), who used only 20 annual reports to examine capital disclosure among mining firms.

Financial institutions were primarily chosen as a research subject because they are heavily regulated and have unique capital structures, which can affect their financial performance (Yermack, 1996; Guest, 2009; Lim et al., 2007). A secondary reason for choosing financial firms was that they mobilise and allocate capital to help other sectors grow and increase productivity. This enhances efficient capital allocation among firms (Levine, 2003). The breakdown of the firms used and other descriptions can be seen in Table 1.

This research also uses panel data analysis because it gives a greater degree of freedom; less collinearity among variables; more cross-sectional and time-series variability; more efficiency and more accounts of observable firm-level heterogeneity in individual-specific variables (see, for example, Gujarati, 2003; Cheng et al., 2008; Ntim et al., 2013, Danso and Adomako, 2014). Used panel data analysis.

\section{[INSERT TABLE 1 HERE]}




\subsection{The regression design}

The data given will be tested using the following regression model:

Tobin's $\mathrm{Q}_{\mathrm{it}}=\alpha_{0}+\alpha_{1}$ Audit Committee $_{\mathrm{it}}+\sum_{\mathrm{i}=2}^{\mathrm{n}} \alpha_{\mathrm{i}}$ CONTROLS $_{\mathrm{it}}+\varepsilon_{\mathrm{it}}$

where:

Tobin's $Q_{i t}$ for firm $i$ at time $t$ is the dependent variable used as a proxy for firm valuation. That is, Tobin's $\mathrm{Q}$ will represent and serve as a firm-based organisational valuation measure. The term $\alpha_{0}$ is constant; the independent variable is Audit Committee (AC). The control variables are growth (GROWTH), capital structure (LEV), size of the firm (FSIZE), Big4 auditing firm, firm is dual-listed (DUAL), Industry (IND), and years of operation (YED). The controls will help reduce any potential omitted variable bias. The last term $\varepsilon_{i t}$ is the model error for firm $i$ at time $t$.

\section{(i) Dependent variable Tobin's Q: firm value}

The dependent variable in this study is firm value, which has also been used in several prior studies; for example, (Agrawal and Knoeber, 1996; Yermack, 1996; Gompers et al., 2003; Klapper and Love, 2004; Beiner et al., 2006; Black et al., 2006; Haniffa and Hudaib, 2006; Henry, 2008; Guest, 2009; Ntim et al., 2015; Krause and Tse, 2016). Tobin's Q represents the financial valuation of corporate governance structures by investors (outsiders), (Lindenberg and Rose, 1981). Tobin's Q is measured as the ratio of total assets minus the book value of equity plus the market value of equity to total assets (Chung and Pruitt 1994, Beiner et al., 2006). Table 2 in the appendix defines Tobin's Q.

\section{(ii) The control variables}

To reduce potential omitted variable bias, several control variables have been selected: growth (GROWTH), capital structure (LEV), firm size (FSIZE), Big4; firms cross-listed (DUAL), industry (IND) and year dummies (YED). These control variables were also previously used by other empirical studies (see, for example, Chenhall and Moers, 2007; van Lent, 2007; Larker and Rusticus, 2008; Black et al., 2006; Henry, 2008; Gompers et al., 2003; Klapper and Love, 2004; Haniffa and Hudaib, 2006; Guest, 2009; Ntim et al., 2015). Table 2 in the appendix defines all the control variables.

\section{[INSERT TABLE 2 HERE]}

\subsection{Data description}

Table 3 in the appendix presents full descriptive statistics of all variables used in conducting the empirical test. The descriptive statistics were calculated to ascertain the distribution of all the variables and their normality. All the empirical figures generally suggest a wide variation similar to prior findings reported in the literature by, for example, Beiner et al. (2006), Henry (2008), Guest (2009) and Ntim (2013). For instance, the minimum of Tobin's Q is 0.00, the maximum is 72.3 and the average is 10.5 . The standard deviation value indicates a wide variation consistent with prior empirical studies (Ntim, 2013).

[INSERT TABLE 3 HERE] 


\subsection{Testing for Multicollinearity}

One issue in multivariate statistical analysis is multicollinearity (Hair et al. 2006). Multicollinearity relates to a case where there is a high correlation between all the independent variables with the dependent variables in a regression model (Kline 1998; Karim et al. 2013). When this situation arises, it can create instability in the regression outcome and therefore there is a need to control this in the regression model. According to Hair et al. (1998), the correlation between any two pairs of explanatory variables should not be greater than 0.80 . In testing for multicollinearity in this research a Pearson Correlation Matrix was examined and the results indicated no high correlation. Table 4 in the appendix indicates the absence of multicollinerarity (Hair et al., 1998; Kline 1998; Karim et al. 2013). The Pearson Correlation Matrix in Table 4 indicates that an AC is positive and statistically significant to a firm's value (Tobin's Q). Likewise, AC indicates a positive and significant impact on LEV and FSIZE.

\section{[INSERT TABLE 4 HERE]}

\section{Empirical Findings}

\subsection{Results}

As indicated in the motivation for the study, this study seeks to:

- Examine the impact of AC adoption on UK financial institutions.

- Provide empirical evidence regarding the effect of the adoption of ACs by UK financial institutions during the 2007/2008 global financial crisis. The performance of financial institutions during the crisis period was critical for the entire economy.

To achieve these objectives, the analysis has been divided into two. The first objective will use the entire data covering the whole sample period (2000 to 2011). The second analysis will split the data into two sub-groups. The first part will cover the pre-crisis period from 2000 to 2006 and the second part will cover the post-crisis period; that is from 2009 to 2011. We will exclude data from the 2007 and 2008 financial years from our second analysis since the financial crisis occurred during that period. This research will follow similar studies carried out by Danso and Adomako (2014) and Mintah (2015).

\section{[INSERT TABLE 5 HERE]}

\subsection{Empirical discussion 1}

Table 5 in the appendix shows the random effects (RE) and the fixed effects (FE) regression results of the establishment of an AC and its impact on a firm's Tobin's Q. The essence of the two-regression model is to show consistency in the statistical results or outcome. The figures show the p-values and the coefficient of each of the variables under consideration. The regression shows 756 observations; the $R^{2}$ for the fixed effects is 0.130 and the p-values for both the random effects and fixed effects are all statistically significant in the regression model.

In terms of the controls, the empirical results indicate that GROWTH and DUAL have a positive and statistically significant effect on firm value as a measure of financial 
performance. This implies that, when firms have higher investment opportunities, they grow much faster and a fast-growing firm will ultimately have a better financial performance, as attested by earlier studies from Durnev and Kim (2005) and Klapper and Love (2004). In terms of a firm's duality, the results mean that, when firms are dual-listed on foreign exchanges, they are more likely to have better corporate governance structures because they are subject to the additional accounting, governance and disclosure requirements of those other foreign stock exchanges. When a firm is robust and faces additional requirements, it will help minimise certain risks and ensure a higher financial performance. The use of controls such as capital structure (LEV), firm size (FSIZE) and the Big4 auditors did not influence firm value (Tobin's Q).

In terms of the financial sectors, the insurance sectors (2) show a weak indication compared to the investment banking sectors (1). The empirical results show that the insurance (2), mortgage (3), and banking (5), sectors did not influence a firm's value as a measure of its financial performance. However, the establishment of an investment trust (4) sector shows a positive and statistically significant relationship to firm value. This implies that investment trust firms made significant financial gains compared to other sectors.

\section{Audit committee (AC)impact on the firm's Tobin's $Q$-firm value}

The empirical results show the relationship between $\mathrm{AC}$ and firm value. The regression results for both the random and fixed effects indicate that the establishment of an AC made a positive and statistically significant contribution to a firm's value as a measure of its financial performance. The two estimations indicate the consistency of the results and reinforce the observation that when a firm has an AC in place, it will help to enhance that firm's value. Our results suggest that the establishment of an $\mathrm{AC}$ by a firm gives a positive signal to the market, which eventually has an impact on the firm's value. A positive and statistically significant firm value (Tobin's Q) gives investors and shareholders confidence that investment in the firm would be profitable.

The results could also mean that the adoption of an AC improves firm value and enhances the essence of the firm's corporate governance mechanism. Our results are consistent with previous empirical research, such as that of Chan and Li, (2008), who used a sample of Fortune 200 publicly traded firms and found that the presence of expert-independent directors on the board and in the AC enhances firm value. Munisi and Randøy, (2013) used publicly listed companies acrosss Sub-Sahara Africa and their results indicate that ACs are positively and significantly associated with firm value and finally, Karim et al. (2013) found a positive and statistically significant association between ACs and firm value (Tobin's Q) during an examination of auditors quality choice by IPO companies in Bangladesh.

This empicial result is also consistent with the first hypothesis (H1), which states that there is a positive and statistically significant relationship between an AC and a firm's value as a measure of financial performance in UK financial institutions. 


\subsection{Empirical discussion 2}

The second part of the analysis focuses on ACs and their firm value during the global financial crisis period in the UK. Table 6 in the appendix presents the regression results for both the pre- and the post-financial crisis periods, where Tobin's Q is used as a measure of firm value. The regression shows 441 and 189 observations for the pre- and post-crisis periods respectively. As indicated during the introduction of the analysis, the second part of the regression excludes 2007/2008 data as the financial crisis happened in this period, thus a total of 126 observations covering the two-year period have been excluded. The $R^{2}$ and the $\mathrm{p}$ values for both the pre- and post-crisis periods are all statistically significant in the regression model.

The empirical results for the control variables indicate that GROWTH, LEV, FSIZE and Big4 did not influence a firm's value during the pre- and post-financial crisis periods. However, a firm's duality (DUAL) shows a positive and statistically significant relationship with firm value during both periods. This suggests that listing a firm in another country has the propensity to influence the firm's value. When firms are listed in other countries, they have to conform to additional regulatory policies. This makes them more robust and helps improve their corporate governance structures.

In terms of the financial sector, insurance and banking services showed positive signs, but were not significant to firm value. However, there was a positive and statistically significant relationship between financial services such as mortgage and investment trusts and the firm value during both periods. This means that each of the financial sectors has the propensity to ensure that the presence of an $\mathrm{AC}$ has a significant impact on a firm.

\section{Audit committee (AC) impact on firm value during the pre- and post-financial crisis periods}

The empirical results amassed during the pre- and post-financial crisis periods indicate that the establishment of an AC during the pre-crisis era had a positive and statistically significant relationship on a firm's value as a measure of performance. Our results suggest that the presence of an $\mathrm{AC}$ in these UK financial firms can ensure that an appropriate monitoring and oversight procedure is followed, with a view to yielding a good financial performance. The pre-crisis results indicate that the market responded positively when a firm had an $\mathrm{AC}$ in place. Also, the board members working on the committee were able to avoid risk taking, which eventually translated into financial performance. Finally, during the pre-crisis period, institutions were perceived to be robust and the market responded positively when the firms had an AC in place. Our empirical result is consistent with previous research by Choi et al. (2004) which reported the positive performance of Korean firms during the fallout from the Asian financial crisis. Studies by Mintah (2015) also show a positive and statistically significant relationship between the Tobin's Q of a firm and independent variables during the pre-crisis period.

In contrast to the pre-crisis results, the empirical evidence gleaned during the post-crisis period reveals that the establishment of an AC during the post-crisis era did not have any effect on a firm's value as a measure of its financial performance. 
The post-crisis results indicate no statistically significant relationship between AC adoption and firm value between 2009 and 2011. The results suggest that even though the financial crisis was over by 2009 , the entire UK economy was experiencing an economic downturn and financial firms were no exception. As the entire economic recovery was very slow, shareholders and investors were still perceiving that financial institutions' internal corporate governance structures were no different from other sectors of the economy. This affected investor confidence and as a result no significant relationship can be seen to exist between the financial value of firms and the establishment of an AC,(Review of HM Treasury's response to the financial crisis report, 2012) .

Supporting this empirical outcome is research by Yermack (1996) reporting that the establishment of an AC board had a negative correlation with a firm's Tobin's Q when using a sample of 452 large US industrial corporations between 1984 and 1991. Yermack's findings are consistent with our research outcome. As Tobin's Q measures the financial valuation of a firm's wealth from the investor's or outsider's perspective, if investors perceived any weakness in a firm's value, this would have a major consequence for the organisation.

The empirical evidence gathered during the pre- and post-financial crisis periods supports the second hypothesis (H2), which states that there is either a positive or a negative relationship between the existence of an audit committee and a firm's value as a measure of financial performance in UK financial firms during the pre- and post-financial crisis periods.

\subsection{Checking the Robustness of the Results}

In checking the robustness of the results, random effects (RE) and fixed effects (FE) were conducted according to the Durbin-Wu-Hausman-Hausman exogeneity test. The tests indicated that the results were consistent with each other and robust. The robustness or sensitivity analysis suggested that the results shown were stable across a number of proxies.

\subsection{Controlling for Endogeneity - additional analyses}

An endogeneity issue occurs when the independent variable is correlated with the error term. In establishing the relationship between $\mathrm{AC}$ and firm financial performance, the regressions were lagged. In controlling for endogeneity, we re-estimated all the regressions with lagged values for all the variables and they were significant. For example, this research followed similar endogeneity work by Fich and Shivdasani (2006). Krishnan et al. (2011), Danso and Adomako (2014), and Zagorchev and Gao (2015).

Although this research has addressed the endogeneity problems by estimating a lagged value for each variable, we admit that it is extremely difficult to eliminate all potential endogenous associations - as has been suggested by prior studies (Ntim 2013).

\section{Summary and Conclusions}

This paper has investigated the association between the adoption of an AC and firm's value using a sample of 63 financial institutions from 2000-2011. This empirical research has underpinned the finding that the establishment of an $\mathrm{AC}$ has a positive and statistically

\footnotetext{
${ }^{4}$ http://www.bbc.co.uk/news/business-20811289, accessed 16/01/17.
} 
significant effect on a firm's value. The pre-crisis period also indicates that the establishment of an AC has a positive and statistically significant effect on a firm's value.

However, the establishment of an AC did not impact on a firm's value during the postfinancial crisis period. The post-crisis results indicate that an AC has no statistically significant relationship with a firm's value. Our results suggest that, even though the financial crisis was over after 2009, the entire UK economy was still experiencing the effects of an economic downturn and financial firms were no exception (Review of HM Treasury's response to the financial crisis report, 2012) . $^{5}$.

This paper contributes to the existing theoretical corporate governance literature in the following ways: the paper reaffirms that the corporate governance code in the UK addresses any agency costs that exist among firms, and the adoption of an $\mathrm{AC}$ as part of a best corporate governance practice will help reduce agency costs and information asymmetry by ensuring that a firm's activities are conducted in line with the principal's and the agent's expectations. Therefore, our result is consistent with agency theory predictions. The paper also gives a better understanding of $\mathrm{AC}$ adoption and its financial impact on UK financial institutions. This supports the given hypotheses and attests that the adoption of an AC by a UK financial institution will improve their corporate governance mechanisms.

This study has additional practical implications for the AC debate. First, the adoption of an $\mathrm{AC}$ by a firm will improve its accountability, transparency and responsiveness to shareholders; the establishment of an $\mathrm{AC}$ enhances the board of directors' monitoring and oversight responsibility, improves a firm's risk management systems; helps to improve audit quality and also influences accounting information delivery (Krause and Tse, 2016; Karim et al. 2013). Furthermore, this research evidence should be useful to policy makers, regulators and practitioners. Policy makers and regulators will have empirical evidence to better understand the impact of various $\mathrm{AC}$ reforms. The results will also encourage practitioners to maintain robust $\mathrm{AC}$ procedures.

In terms of research limitations, this paper only examines UK financial institutions, and so the results may not be widely applicable to other sectors of the economy. Future studies can look at the impact of ACs in other sectors; for example, its impact on the manufacturing industry in the UK during the pre- and post-crisis periods. Other future studies can also look at the effect of the establishment of an $\mathrm{AC}$ on the composition of boards of directors.

\section{References:}

Aanu, O. S. Odianonsen, I. F. and Foyeke, O. I. (2014), Effectiveness of Audit Committee and Firm Financial Performance in Nigeria: An Empirical Analysis, Journal of Accounting and Auditing: Research \& Practice, Volume 2014, DOI: 10.5171/2014.301176.

Abdul Rahman, R. and Mohamed Ali, F.H. (2006), Board, audit committee, culture and earnings management: Malaysian evidence. Managerial Auditing Journal, 21 (7). 783-804.

Agrawal, A. and Knoeber, C. R. (1996), 'Firm Performance and Mechanisms to Control Agency Problems between Managers and Shareholders', Journal of Financial and Quantitative Analysis, Volume 31, page 377-389.

${ }^{5}$ http://www.bbc.co.uk/news/business-20811289, accessed 16/01/17. 
April, K. A., Bosma, P. and Deglon, D. A. (2003), 'IC Measurement and Reporting: Establishing a Practice in SA Mining', Journal of Intellectual Capital, Volume 4, No. 2, page 165-180.

Baldenius, T. Melumad, N. and Meng, X. (2014), Board composition and CEO power, Journal of Financial Economics, 11253-68.

Bank of England (BoE) (2014), Prudential regulation on Banks.

http://www.bankofengland.co.uk/PRA/Pages/default.aspx, accessed 10/03/14.

Basel Committee on Banking Supervision, (2010), Principle for Enhancing Corporate Governance, Basel, Switzerland.

Beiner, S., Drobetz, W., Markus, M. and Zimmermann, H. (2006), 'An Integrated Framework of Corporate Governance and Firm Valuation', European Financial Management, Volume 12, No. 2, page 249-283.

Berle, A.A. and Means, G.C. (1932), The Modern Corporation and Private Property. New York: Macmillan.

Black, B. S., Jang, H. and Kim, W. (2006), 'Does Corporate Governance Predict Firm's Market Values? Evidence from Korea, Journal of Law, Economics and Organization, Volume 22, No. 2, page 366-413.

Botosan, C. A. (1997), 'Disclosure Level and the Cost of Equity Capital', Accounting Review, Volume 72, No. 3, page 323-350.

Bozec, R. (2005), Boards of Directors, Market Discipline and Firm Performance. Journal of Business Finance \& Accounting, 32(9) and (10), November/December 2005, 0306-686X.

Bradbury, M.E., Y.T. Mak, S.M. Tan (2006), Board characteristics, audit committee characteristics and abnormal accruals, Pacific Accounting Review, 18, page 47-68.

Bruynseels L. and Cardinaels, E. (2014), The Audit Committee: Management Watchdog or Personal Friend of the CEO? The Accounting Review, American Accounting Association, Volume 89, No.1 2014, page 113-145 DOI: 10.2308/accr-50601.

Cadbury Committee Report (1992), The Report of the Committee on the Financial Aspects of Corporate Governance, Gee Publishing, London.

Carcello, J. V., and T. L. Neal, (2003a), Audit committee characteristics and auditor dismissals following 'New" Going-concern reports, The Accounting Review 78, 95-117.

Carcello, J. V., and T. L. Neal, (2003b), Audit committee independence and disclosure: choice for financially distressed firms, Corporate Governance: An International Review 11, 289-299.

Carcello, J. V., Hermanson, D. R., Neal, T. L. and Riley, R. A. (2002), 'Board Characteristics and Audit Fees', Contemporary Accounting Research, Volume 19, No. 2, page 365-384. 
Chan, K. C., and J. Li, (2008), ),“Audit committee and firm value: evidence on outside top executives as expert-independent directors" Corporate Governance: An International Review 16, 16-31.

Charkham, J. (2005), Keeping better company: corporate governance ten years on. Oxford: Oxford University Press.

Cheng, S., Evans, J. H. and Nagarajan, N. J. (2008), 'Board Size and Firm Performance: Moderating Effects of the Market for Corporate Control', Review of Quantitative Financial Accounting, Volume 31, page 121-145.

Chenhall, R. and Moers, F. (2007b), 'Endogeneity: A Reply to Two Different Perspectives', European Accounting Review, Volume 16, No. 1, page 217-221.

Chenhall, R. H. and Moers, F. (2007a), 'The Issue of Endogeneity within Theory-Based, Quantitative Management Accounting Research', European Accounting Review, Volume 16, No. 1, page 173-195.

Cheung, W. K. A. and Wei, K. C. J. (2006), Insider Ownership and Corporate Performanc: Evidence from the Adjustment Cost Approach', Journal of Corporate Finance, Volume 12, page 906-925.

Choi, J. H. Jeon, K. and Prk, J. (2004), The Role of Audit Committee in Decreasing Earning Management: Korean Evidence." International Journal of Accounting, Auditing and Performance Evaluation, Volume 1, No. (1), (2004), 37-60.

Chong, G. (2015), "International insurance audits and governance', International Journal of Accounting \& Information Management, Vol. 23 Issue: 2, pp.152-168.

Chung, K. H. and Pruitt, S. W. (1994), 'A Simple Approximation of Tobin's Q', Financial Management, Volume 23, No. 3, page70-74.

Collier, P. (1993), "Factors affecting the formation of audit committees in major UK listed companies ”, Accounting and Business Research, Volume 23, No. 91A, page 421-430.

Combined Code (2003), Combined Code on Corporate Governance, Financial Reporting Council, London.

Combined Code (2006), Combined Code on Corporate Governance, Financial Reporting Council, London.

Conyon, M. J. (1994), 'Corporate Governance Changes in UK Companies Between 1988 and 1993', Corporate Governance, Volume 2, No. 2, page 87-99.

Danso, A; and S; Adomako (2014), The financial behavior of firms and financial crisis, Managerial Finance, Volume 40, No.12, 2014; Emerald Group Publishing Limited.

Defond, M. L., R. N. Hann, and H. U. Xuesong. (2005), Does the market value financial expertise on audit committees of boards of directors? Journal of Accounting Research 43 (2):153-193. 
Durnev, A. and Kim, E. H. (2005), 'To Steal or Not to Steal: Firm Attributes, Legal Environment, and Valuation', Journal of Finance, Volume LX, No. 3, page 1461-1493.

Eisenhardt, M.K (1989), Agency Theory: An Assessment and Review, The Academy of Management Review, Volume14, No. 1, page 57-74.

Fama E. F. and Jensen, M. C. (1983), 'Separation of Ownership and Control', Journal of Law and Economics, Volume 26, No. 2, page 301-325.

Fama, E. F. (1980), Agency problems and the theory of the firm', Journal of Political Economy, 88, 288-307.

Felo, A. J., Krishnamurthy, S. and Solieri, S. A. (2003), Audit committee characteristics and the perceived quality of financial reporting: An empirical analysis, Working paper, Pennstate Great Valley.

Fich, E. M. and Shivdasani, A. (2006), 'Are Busy Boards Effective Monitors?', Journal of Finance, Volume LXI, No. 2, page 689-724.

Financial Reporting Council (2014),https://www.frc.org.uk/Our-

Work/Publications/Corporate-Governance/Guidance-on-Audit-Committees-September2014.aspx.

Financial Reporting Council (2016), https://www.frc.org.uk/OurWork/Publications/Corporate-Governance/Guidance-on-Audit-Committees-September2016.aspx.

Financial Service Authority Review Report (2002), on effective corporate governance, accessed on $15^{\text {th }}$ January 2015.

Financial Service Bill available at HM Treasury, Accessed from $20^{\text {th }}$ January, 2015.

Firer, C. and Meth, G. (1986), 'Information Disclosure in Annual Reports in South Africa', Omega: The International Journal of Management Science, Volume 14, No. 5, page 373-382.

Global Corporate Governance Principles: Revised (2009), International Corporate Governance Network, ICGN, 2009.

Gompers, P., Ishii, J. and Metrick, A. (2003), 'Corporate Governance and Equity Prices', Quarterly Journal of Economics, Volume 118, page107-155.

Greenbury, R., (1995), Directors' Remuneration: Report of A Study Group. Gee Publishing, London.

Guest, P. M. (2009), 'The Impact of Board Size on Firm Performance: Evidence from the UK', The European Journal of Finance, Volume 15, No. 4, page 385-404.

Gujarati, D. N. (2003), Basic Econometrics, 4th Edition, McGraw-Hill Companies, New York, USA. 
Hair, J. F. J., Anderson, R. E. Tatham, R. L and Black, W. C. (1998), Multivariate Data Analysis. New York: Macmillan.

Hair, J. F. J., Anderson, R. E. Tatham, R. L and Black, W. C. (2006), Multivariate Data Analysis with Readings. New York: Macmillan.

Hampel, R., (1998), Committee on Corporate Governance: Final Report. Gee, London.

Haniffa, R. and Hudaib, M. (2006), 'Corporate Governance Structure and Performance of Malaysian Listed Companies', Journal of Business, Finance and Accounting, Volume 33, No. 7 \& 8, page 1034-1062.

Hausman, J. A. (1978), 'Specification tests in econometrics' Econometrica, 46 (6): 12511271. ISSN 0012-9682.

Henry, D. (2008), 'Corporate Governance Structure and the Valuation of Australian Firms: Is there Value in Ticking the Boxes', Journal of Business Finance and Accounting, Volume 35, No. $7 \& 8$, page $912-942$.

Higgs, D. (2003), Review of the Role and Effectiveness of Non-Executive Directors. London: UK Department of Trade and Industry. HM Treasury: https://www.gov.uk/government/publications,(03/2/14).

Hill, C.W.L. and Jones, T.M. (1992), 'Stakeholder-agency theory', Journal of Management Studies, Volume 29, No. 2: 131-54.

Hillman, A.J., and Dalziel, T., (2003), Boards of directors and firm performance: integrating agency and resource dependence perspectives; Academy of Management Review. 28, 383396.

HM Treasury (2012), Response to the financial crisis report, https://www.gov.uk/government/publications/review-of-hm-treasurys-response-to-thefinancial-crisis-2007-09, accessed $16^{\text {th }}$ January, 2017.

HM Treasury (2015), https://www.gov.uk/government/publications; accessed $10^{\text {th }}$ January, 2015.

Ho, C.A. and Williams, S. M. (2003), 'International Comparative Analysis of the Association between Board Structure and the Efficiency of Value Added by a Firm from its Physical Capital and Intellectual Capital Resources', The International Journal of Accounting, Volume 38, page 465-491.

Huse, M. (2007), Board, Governance and Value Creation: The Human Side of Corporate governance, published.

Jensen, M. C. and Meckling, W. H. (1976), 'Theory of the Firm: Managerial Behaviour, Agency costs and Ownership Structure', Journal of Financial Economics, Volume 3, page 305-360. 
Kang, H., Cheng, M., and Gray, S. J. (2007), Corporate governance and board composition: Diversity and independence of Australian boards. Corporate Governance: An International Review, 15, 194-207.

Karamanou, I. and Vefeas, N. (2005), The association between corporate boards, audit committees, and management earnings forecasts: An empirical analysis. Journal of Accounting Research, 43(3), 453-486.

Karim, W.A.K.M., Zijl, V. T. and Mollah, S. (2013), "Impact of board ownership, CEOChair duality and foreign equity participation on auditor quality choice of IPO companies: evidence from an emerging market", International Journal of Accounting \& Information Management, Vol. 21 No. 2, pp. 148-169.

Klapper, L. F. and Love, I. (2004), 'Corporate Governance, Investor Protection, and Performance in Emerging Markets', Journal of Corporate Finance, Volume 10, page 703728.

Klein, A., (1998), Firm performance and board committee structure, The Journal of Law and Economics 41, 275-304.

Kline, R.B. (1998), Principles and Practices of Structural Equation Modelling. New York, Guilford Press.

Krause, A. T., and Tse, Y, (2016), "Risk management and firm value: recent theory and evidence", International Journal of Accounting and Information Management, Vol. 24 Issue: 1, pp.56-81.

Khosa, A. (2017), "Independent directors and firm value of group-affiliated firms", International Journal of Accounting \& Information Management, Vol. 25 Issue: 2, pp.217236.

Krishnan, C. N. V., Vladimir Ivanov, Ronald Masulis, and Ajai Singh (2011), Venture Capital Reputations, Post-IPO Performance, and Corporate Governance. Journal of Financial and Quantitative Analysis, Volume 46(5):1295-1333.

Larker, D. F. and Rusticus, T. O. (2008), 'On the Use of Instrumental Variables in Accounting Research', Working Paper.

Levine, R. (2003), The Corporate Governance of Banks- A Concise Discussion of Concepts and Evidence July 21 (2003).

Lim, S., Matolcsy, Z. and Chow, D. (2007), 'The Association between Board Composition and Different Types of Voluntary Disclosure', European Accounting Review, Volume 16, No. 3, page 555-583.

Lindenberg, E.B. and Ross, S.A. (1981), Tobin's Q Ratio and Industrial Organization, Journal of Business, 54, page 1-33. 
Macey, J. R., and O'Hara, M. (2003), The corporate governance of banks, FRBNY, Economic Policy Review, 9, 91-107.

Mallin, C. A. (2006), Handbook on International Corporate Governance, Edward Elgar Publishing, Cheltenham, UK.

Mangena, M. and Chamisa, E. (2008), 'Corporate Governance and Incidences of Listings Suspension by the JSE Securities Exchange of South Africa: An Empirical Analysis', The International Journal of Accounting, Volume 43, page 28-44.

Menon, K., and J.D. Williams. (1994), The use of audit committees for monitoring. Journal of Accounting and Public Policy, 13, 121-139.

Mintah, A.P. (2016), Remuneration committee governance and firm performance in UK financial firms; Investment Management and Financial Innovation Journal, Volume 13, Issue $1,2016$.

Mintah, A. P. (2015), The Nomination Committee and Firm Performance; An Empirical Investigation of UK Financial Institutions during the pre/post financial crisis, Corporate Board; Role, Duties \& Compositions, Volume 11, Issue 3, 2015.

Mizen, P. (2008), The Credit Crunch of 2007-2008; A Discussion of the Background, Market Reactions and Policy Responses, Federal Reserve Bank of St. Louis Review, page 531-67.

Munisi, G. and Randøy, T. (2013), Corporate governance and company performance across Sub-Sahara African countries, Journal of Economics and Business, 70 (2013) 92- 110.

Myners, P. (2001), Myners Report on Institutional Investment. London: HM Treasury, 2008.

Ntim G. C.; Opong, K.K.; and Danbolt, J., (2015), Board size, corporate regulations and firm valuation in an emerging market: a simultaneous equation approach, International Review of Applied Economics, 2015; Volume 29, No. 2, page 194-220.

Ntim, G. C. (2013), Corporate ownership and market valuation in South Africa: uncovering the effects of shareholdings by different groups of corporate insiders and outsiders, International Journal of Business Governance and Ethics, 2013 Volume 8, No.3, page 242 264.

Ntim, G. C. Lindop, S. and Thomas, D.A. (2013), Corporate governance and risk reporting in South Africa: A study of corporate risk disclosures in the pre- and post-2007/2008 global financial crisis periods. International Review of Financial Analysts 30 (2013) 363-383.

OECD (2009), OECD Principles of Corporate Governance, Organisation for Economic Cooperation and Development, (OECD) Paris, France.

Smith, R. (2003), Audit Committees Combined Code Guidance, Financial Reporting Council, London.

Turnbull, N. (1999), Internal Control: Guidance for Directors on the Combined Code, Institute of Chartered Accountants in England and Wales, London, (ICAEW). 
Turnbull, N. (2005), Internal Control: Guidance for Directors on the Combined Code, Institute of Chartered Accountants in England and Wales, London, (ICAEW).

Turner Review (2009), A Regulatory Response to the Global Banking Crisis, Financial Services Authority, London, UK.

Tyson, L (2003), The Tyson Report on the Recruitment and Development of Non-Executive Directors. London: London Business School.

Van der Zahn, M. and G. Tower, (2004), Audit committee features and earnings management: further evidence from Singapore, International Journal of Business Governance and Ethics 1, 233-257.

Van Lent, L. (2007), 'Endogeneity in Management Accounting Research: A Comment', European Accounting Review, Volume 16, No. 1, page 197-205.

Vefeas, N. and Theodorous, E. (1998), The relationship between board structure and firm performance in the UK. British Accounting Review, 30(4), 383-407.

Walker Review (2009), A Review of Corporate Governance in UK Banks and Other Financial Industry entities, HM Treasury, London, UK.

Wild, J. J. (1994), 'Managerial Accountability to Shareholders: Audit Committees and the Explanatory Power of Earnings for Returns', British Accounting Review, Volume 26, page 353-374.

Yermack, D. (1996), 'Higher Market Valuation of Companies with a Small Board of Directors', Journal of Financial Economics, Volume 40, page 185-211.

Zagorchev, A. and Gao L. (2015), Corporate governance and performance of financial institutions, Journal of Economics and Business.

Zha, H. (2006), 'The Auditing Committee and Earnings Quality: Empirical Evidence from Chinese Securities Market (Chinese Version)'. Auditing Research, 6:50-57 


\section{Appendix}

A breakdown of the firms used and other descriptions can be seen in Table 1 .

Table 1: Classification and Representation of Variables

\begin{tabular}{|c|c|c|c|c|}
\hline & Variables & Representation & & \\
\hline \multirow{2}{*}{$\begin{array}{l}\text { Audit Committee } \\
\text { (AC) }\end{array}$} & Does exist & 1 & & \\
\hline & Does not exist & 0 & & \\
\hline \multirow[t]{7}{*}{ Industry (IND) } & $\begin{array}{l}\text { List of Financial } \\
\text { Institutions }\end{array}$ & Representation & Percentage & Numbers \\
\hline & Investment Banking & 1 & 29 & 18 \\
\hline & Insurance & 2 & 21 & 13 \\
\hline & Mortgages & 3 & 19 & 12 \\
\hline & Investment Trust & 4 & 17 & 11 \\
\hline & Banking Services & 5 & 14 & 9 \\
\hline & Total & & 100 & 63 \\
\hline \multirow{7}{*}{$\begin{array}{l}\text { Big4Auditors } \\
\text { (BIG4) }\end{array}$} & & Representation & & \\
\hline & Deloitte \& Touche & 1 & & \\
\hline & $\begin{array}{l}\text { PriceWaterhouse } \\
\text { Coopers }\end{array}$ & 1 & & \\
\hline & Ernst \& Young & 1 & & \\
\hline & KPMG & 1 & & \\
\hline & Grant Thornton & 0 & & \\
\hline & BDO International & 0 & & \\
\hline \multirow{2}{*}{$\begin{array}{l}\text { Firms Cross-listed } \\
\text { (DUAL) }\end{array}$} & Does exist & 1 & & \\
\hline & Does not exist & 0 & & \\
\hline Pre-financial crisis & $2000-2006$ & 0 & & \\
\hline $\begin{array}{l}\text { Financial crisis } \\
\text { period }\end{array}$ & $2007-2008$ & - & & \\
\hline Post-financial crisis & 2009-2011 & 1 & & \\
\hline
\end{tabular}


Table 2: Summary of definitions and explanation of variables

\begin{tabular}{|c|c|}
\hline $\begin{array}{l}\text { Dependent } \\
\text { Variables }\end{array}$ & \\
\hline $\begin{array}{l}\text { Tobin's } Q \text { (Tobin's } \\
Q)\end{array}$ & $\begin{array}{l}\text { Tobin's Q (Tobin's Q) is defined as the market value of equity plus the book } \\
\text { value of total assets minus the book value of equity divided by the book } \\
\text { value of total assets (Chung and Pruitt, 1994; Beiner et al., 2006). }\end{array}$ \\
\hline \multicolumn{2}{|l|}{ Independent variable: } \\
\hline $\begin{array}{l}\text { Audit Committee: } \\
(A C)\end{array}$ & $\begin{array}{l}\text { The audit committee (AC) is the independent variable (see for example; } \\
\text { Smith review, 2003, Walker review, 2009). If the firm has an audit } \\
\text { committee it is given a value of } 1 \text {, if it has no AC it has a value of } 0 \text {. }\end{array}$ \\
\hline \multicolumn{2}{|l|}{ Control Variables: } \\
\hline Growth: (GROWTH) & $\begin{array}{l}\text { Firm which have higher investment opportunities end up growing much } \\
\text { faster (Durnev and Kim, 2005). A faster growing firm may receive higher } \\
\text { valuation and better performance in the future (Klapper and Love, 2004). } \\
\text { Growth is the ratio of sales growth to total assets growth. }\end{array}$ \\
\hline $\begin{array}{l}\text { Capital Structure } \\
(L E V)\end{array}$ & $\begin{array}{l}\text { Modigliani and Miller (1963) suggested that a firm's capital structure can } \\
\text { have an impact on its profitability. Capital structure is the percentage of total } \\
\text { debt to total assets. }\end{array}$ \\
\hline Firm Size (FSIZE) & $\begin{array}{l}\text { Larger firms receive higher market valuations and enjoy lower external } \\
\text { capital costs (Botosan, 1997). Contrarily, Klapper and Love (2004) suggest } \\
\text { that smaller firms tend towards better growth opportunities and greater } \\
\text { external financing. Firm size is the natural log of total assets. Karim et al. } \\
\text { (2013), a large firm would want to employ a more highly regarded auditor. } \\
\text { A large firm size has a bigger volume of transactions under audit. }\end{array}$ \\
\hline Big four (BIG4) & $\begin{array}{l}\text { 1, if the firm is audited by a big four firm (PricewaterhouseCoopers, Deloitte } \\
\& \text { Touche, Ernst\& Young and KPMG), } 0 \text { otherwise. }\end{array}$ \\
\hline $\begin{array}{l}\text { Foreign/Dual- } \\
\text { Listing (DUAL) }\end{array}$ & $\begin{array}{l}\text { Firms that have a dual listing on foreign exchange are more likely to have } \\
\text { better corporate governance structures. This is because they are subject to } \\
\text { the additional accounting, governance and disclosure requirements of the } \\
\text { foreign stock exchanges, which are cross-listed (Haniffa and Cooke, 2002; } \\
\text { Black et al., 2006). A dummy variable is used, if the firm is dual-listed } 1 \\
\text { otherwise } 0 \text {. }\end{array}$ \\
\hline Industry (IND) & $\begin{array}{l}\text { This shows the sector a firm operates in. This research classifies financial } \\
\text { institutions into 5-sectors/industries, namely: 1. Investment services; } 2 . \\
\text { Insurance; } 3 \text {. Mortgages; } 4 \text {. Investment Trust; 5. Banking Services. }\end{array}$ \\
\hline Year Dummy (YED) & $\begin{array}{l}\text { The time in a particular year in which a firm starts business can have an } \\
\text { impact on its profitability. The years chosen for the research run from } 2000 \\
\text { to } 2011 \text {. They are represented as follows: } 2000 \text { (YED); } 2001 \text { (YED); } 2002 \\
\text { (YED); } 2003 \text { (YED); } 2004 \text { (YED); } 2005 \text { (YED); 2006 (YED); } 2007 \text { (YED); } \\
2008 \text { (YED); } 2009 \text { (YED); } 2010 \text { (YED; } 2011 \text { (YED). }\end{array}$ \\
\hline
\end{tabular}


Table 3: Descriptive Statistics for all the variables

\begin{tabular}{lcccccc}
\hline & Count & Mean & Median & Std. Dev. & Min & Max \\
\hline Tobin's Q & 756 & 10.461 & 5.881 & 13.066 & 0 & 72.712 \\
AC & 756 & 0.538 & 1 & 0.499 & 0 & 1 \\
GROWTH & 756 & 0.239 & 0.116 & 0.457 & 0 & 6.19 \\
LEV & 756 & 2.027 & 1.231 & 2.572 & 0 & 17.617 \\
FSIZE & 756 & 9.911 & 13.143 & 6.214 & 0.073 & 19.709 \\
BIG4 & 756 & 0.968 & 1 & 0.175 & 0 & 1 \\
DUAL & 756 & 0.968 & 1 & 0.175 & 0 & 1 \\
IND & 756 & 3.333 & 3 & 1.334 & 1 & 5 \\
\hline
\end{tabular}

Notes: The above table shows 756 observations of the various variables with their mean, median, standard deviations, minimum and maximum values. Tobin's Q (Tobin's Q): is defined as is defined as the market value of equity plus the book value of total assets minus the book value of equity divided by the book value of total assets. AuditCom: Is responsible for reviewing financial statement, firm's internal financial controls, risk management systems and ensure the objectivity of the audit process is maintained (FRC, 2014). Growth: Is defined as the ratio of sales growth to total assets growth; Capital Structure (LEV) is defined as the Percentage of total debt to total assets. FSIZE: Is defined as the natural log of total assets.; BIG4- are (PricewaterhouseCoopers, Deloitte \& Touche, Ernst\& Young and KPMG); DUAL: Is defined as a situation where the firm is cross-listed in other countries. IND: This shows the sector a firm operates in. This research classifies financial institutions into 5-sectors/ industries, namely: 1. Investment services 2. Insurance 3. Mortgages 4. Investment Trust 5. Banking Service.

Table 4: Pearson correlation matrix

\begin{tabular}{ccccccccc} 
& Tobin's Q & AC & GROWTH & LEV & FSIZE & BIG4 & DUAL & IND \\
\hline Tobin's Q & 1 & & & & & & & \\
AC & $0.248^{* * *}$ & 1 & & & & & & \\
GROWTH & 0.019 & 0.006 & 1 & & & & & \\
LEV & -0.044 & $0.217^{* * *}$ & -0.057 & 1 & & & \\
FSIZE & -0.012 & $0.096^{* * *}$ & -0.017 & $-0.148^{* * *}$ & 1 & & \\
BIG4 & -0.013 & -0.016 & -0.029 & 0.017 & $-0.092^{* *}$ & 1 & \\
DUAL & $0.065^{*}$ & 0.029 & -0.031 & 0.04 & $0.137^{* * *}$ & -0.033 & 1 & \\
IND & -0.026 & -0.003 & -0.047 & $-0.222^{* * *}$ & $0.193^{* * *}$ & $-0.226^{* * *}$ & $-0.091^{* *}$ & 1 \\
\hline
\end{tabular}

Note: Table 4 represent the Pearson's correlation coefficients. Variables are defined as follows: Tobin's Q which represents the market value of the firm; Audit Committee (AC); GROWTH; LEV; FSIZE; BIG4 are (PricewaterhouseCoopers, Deloitte \& Touche, Ernst\& Young and KPMG);DUAL; Industry which classifies the financial sector as 1. Investment services; 2 . Insurance; 3. Mortgages; 4 . Investment Trust; 5. Banking Services. $" *{ }^{*}$ " and " denote correlation and are significant at the $1 \%, 5 \%$ and $10 \%$ level, respectively. 
Table 5: Audit Committee (AC) impact on a firm's Tobin's Q Results

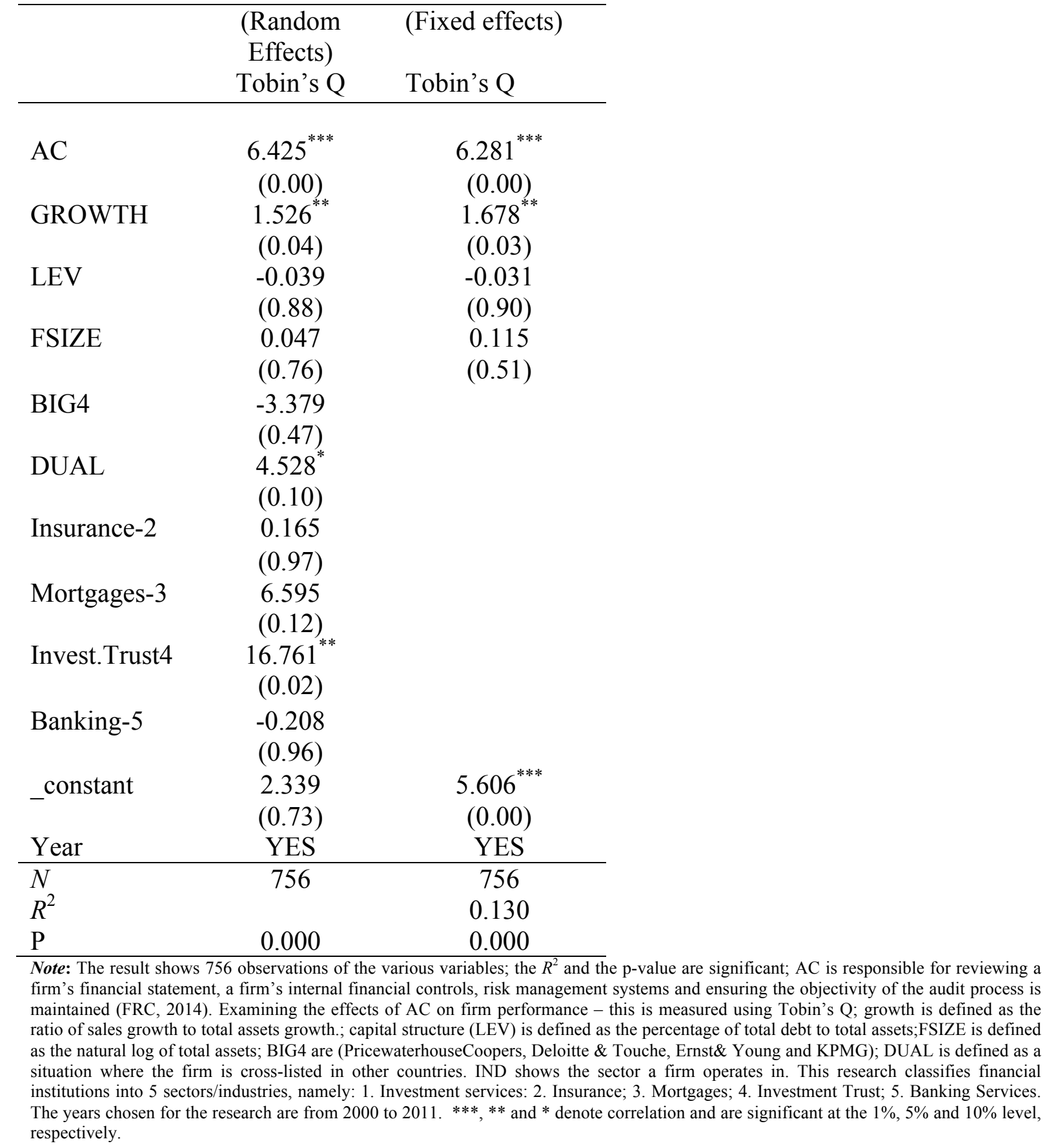


Table 6: The Pre- and Post-financial Crisis Effects on Tobin's $Q$

\begin{tabular}{|c|c|c|}
\hline & $\begin{array}{c}\text { (Pre-Crisis) } \\
\text { Tobin's Q }\end{array}$ & $\begin{array}{c}\text { (Post-Crisis) } \\
\text { Tobin's Q } \\
\end{array}$ \\
\hline $\mathrm{AC}$ & $\begin{array}{c}7.624^{* * *} \\
(0.00)\end{array}$ & $\begin{array}{l}-1.117 \\
(0.65)\end{array}$ \\
\hline GROWTH & $\begin{array}{l}-0.094 \\
(0.88)\end{array}$ & $\begin{array}{l}-2.380 \\
(0.11)\end{array}$ \\
\hline LEV & $\begin{array}{l}0.089 \\
(0.66)\end{array}$ & $\begin{array}{l}-0.189 \\
(0.62)\end{array}$ \\
\hline FSIZE & $\begin{array}{l}-0.034 \\
(0.70)\end{array}$ & $\begin{array}{l}-0.380 \\
(0.10)\end{array}$ \\
\hline BIG4 & $\begin{array}{l}-0.887 \\
(0.48)\end{array}$ & $\begin{array}{l}-8.898^{*} \\
(0.06)\end{array}$ \\
\hline Dual & $\begin{array}{l}2.855^{* *} \\
(0.04)\end{array}$ & $\begin{array}{c}8.568^{* * *} \\
(0.00)\end{array}$ \\
\hline Insurance-2 & $\begin{array}{l}1.579 \\
(0.44)\end{array}$ & $\begin{array}{l}4.203 \\
(0.26)\end{array}$ \\
\hline Mortgages-3 & $\begin{array}{c}4.864^{* *} \\
(0.02)\end{array}$ & $\begin{array}{c}15.358^{* * * *} \\
(0.00)\end{array}$ \\
\hline Invest. Trust-4 & $\begin{array}{c}16.385^{* * *} \\
(0.00)\end{array}$ & $\begin{array}{c}24.285^{* * *} \\
(0.00)\end{array}$ \\
\hline Banking-5 & $\begin{array}{l}1.115 \\
(0.58)\end{array}$ & $\begin{array}{l}2.981 \\
(0.45)\end{array}$ \\
\hline _constant & $\begin{array}{l}-0.149 \\
(0.96)\end{array}$ & $\begin{array}{c}12.471^{*} \\
(0.05)\end{array}$ \\
\hline Year & YES & YES \\
\hline$N$ & 441 & 189 \\
\hline$R^{2}$ & 0.206 & 0.194 \\
\hline $\mathrm{p}$ & 0.000 & 0.000 \\
\hline
\end{tabular}

